\title{
Radio-resistant mesenchymal stem cells: mechanisms of resistance and potential implications for the clinic
}

\author{
Nils H. Nicolay ${ }^{1,2,3}$, Ramon Lopez Perez ${ }^{2,3}$, Rainer Saffrich ${ }^{4}$ and Peter E. Huber ${ }^{1,2,3}$ \\ ${ }^{1}$ Department of Radiation Oncology, Heidelberg University Hospital, Heidelberg, Germany \\ ${ }^{2}$ Heidelberg Institute for Radiation Oncology (HIRO), National Center for Radiation Research in Oncology, Heidelberg, \\ Germany \\ ${ }^{3}$ Department of Molecular and Radiation Oncology, German Cancer Research Center (dkfz), Heidelberg, Germany \\ ${ }^{4}$ Department of Hematology and Oncology, Heidelberg University Hospital, Heidelberg, Germany \\ Correspondence to: Nils H. Nicolay, email: n.nicolay@dkfz.de \\ Keywords: mesenchymal stem cell, radiotherapy, double strand break, tissue regeneration
}

Received: May 17, 2015

Accepted: May 30, 2015

Published: June 08, 2015

This is an open-access article distributed under the terms of the Creative Commons Attribution License, which permits unrestricted use, distribution, and reproduction in any medium, provided the original author and source are credited.

\section{ABSTRACT}

Mesenchymal stem cells (MSCs) comprise a heterogeneous population of multipotent stromal cells and can be isolated from various tissues and organs. Due to their regenerative potential, they have been subject to intense research efforts, and they may provide an efficient means for treating radiation-induced tissue damage. MSCs are relatively resistant to ionizing radiation and retain their stem cell characteristics even after high radiation doses. The underlying mechanisms for the observed MSC radioresistance have been extensively studied and may involve efficient DNA damage recognition, double strand break repair and evasion of apoptosis. Here, we present a concise review of the published scientific data on the radiobiological features of MSCs. The involvement of different DNA damage recognition and repair pathways in the creation of a radioresistant MSC phenotype is outlined, and the roles of apoptosis, senescence and autophagy regarding the reported radioresistance are summarized. Finally, potential influences of the radioresistant MSCs for the clinic are discussed with respect to the repair and radioprotection of irradiated tissues.

\section{INTRODUCTION}

Mesenchymal stem cells (MSCs) were first characterized by Friedenstein et al. in 1974 after isolation from mouse bone marrow [1]; they were initially described as colony-forming, spindle-shaped cells, able to rapidly adhere to plastic surfaces and differentiate into adipocytes, chondrocytes and fibroblasts. Unlike their bone marrow-derived hematopoietic counterparts, MSCs form heterogeneous populations; to account for this fact and to differentiate them from embryonic stem cells, they are sometimes termed multipotent mesenchymal stromal cells $[2,3]$. MSCs express various cell surface proteins, including CD13, CD29/ITGB1, CD44, CD73, CD90, CD105/ENG and CD106/VCAM-1 and lack hematopoietic surface markers CD31, CD34, CD45 and CD116 [4, 5]. However, a unique pattern of surface markers has yet to be generally accepted to prospectively identify MSCs; therefore, functional aspects such as the cells' fibroblast-like appearance, their ability to rapidly adhere to plastic surfaces and form colonies in culture and their potential for differentiation along the osteogenic, chondrogenic and adipogenic lineage are commonly employed to further characterize MSCs [6]. A combination of functional characteristics and molecular marker expression patterns has been suggested as minimal criteria for defining multipotent MSCs [7]. Beyond their appearance in the bone marrow, MSCs have been detected and isolated from a broad variety of other tissue types including vascular, adipose and skin tissues, kidney, umbilical cord and placenta [6, 8-10].

As MSCs were first isolated from bone marrow, their physiological function has been most widely studied in the context of this organ. The adult bone marrow contains the key lineages of hematopoietic stem cells (HSCs) and maintains and proliferates them according to demand [11]. HSCs are kept in a specialized microenvironment, termed the HSC niche, containing 
various other supporting cell types, including MSCs [12-14]. These supporting cells have been shown to secret extracellular matrix proteins such as VCAM-1, $\mathrm{N}$-cadherin or annexin II, providing a scaffold for HSC retention $[15,16]$. Additionally, the regulation of HSC proliferation, mobilization or differentiation is intricately controlled within the stem cell niche by the secretion of different signaling molecules, among them growth factors, chemokines and cytokines [17, 18]. MSCs have been among the most well-characterized supporting cells in the HSC niche, and similar functions regarding organ-specific cellular homeostasis have been attributed to MSCs based in lung tissue or blood vessels [19, 20].

Despite the fact that the physiological roles of MSCs are only incompletely understood, these cells have been subject to intensive research in recent years, as they may hold the potential to participate in the repair of tissue damage. Animal studies have shown their ability to migrate and integrate into damaged organs and differentiate into organ-specific, functional cells [21, 22]. Additionally, MSCs may create a protective and nurturing microenvironment inside damaged tissue by secreting a multitude of growth factors and cytokines, among them stem cell factor (SCF), vascular endothelial growth factor (VEGF), basic fibroblast growth factor (bFGF), hepatocyte growth factor (HGF), angiopoietin, plateletderived growth factor (PDGF), transforming growth factor $\beta$ (TGF- $\beta$ ), nerve growth factor (NGF) and brain-derived neurotrophic factor (BDNF), thereby aiding other cells in the regeneration of damage [23-32]. The regenerative potential of MSCs has widely been shown in vitro and in animal models, and the beneficial effects of MSCs have been discussed for various forms of tissue damage, including myocardial scars, cartilage injuries, pulmonary damage as well as skin and nerve tissue defects [33-35].

While the regenerative properties of MSCs have been well examined in the context of ischemic or mechanic tissue lesions, these effects may also be applicable to other forms of damage, especially the detrimental effects of ionizing radiation on treated or exposed normal tissues. A potential use of MSCs in the context of radiation-induced tissue lesions is supported by the radioresistant phenotype of this cell type. This review summarizes the current knowledge on the radiobiological features of these stem cells and highlights potential applications and challenges regarding the MSC-based repair of radiation damage.

\section{CELLULAR EFFECTS OF IONIZING RADIATION}

\section{DNA damage signaling}

Ionizing radiation exerts its effects mostly on the cells' genomic information, either by directly depositing its energy onto DNA molecules or by creating free radicals that in turn interact with the DNA strands [36]. Depending on the energy transfer, irradiation creates various different forms of DNA damage, including damage to DNA bases or the sugar backbone as well as complex, clustered strand breaks that contain different DNA lesions with one region of the DNA [37]. While base damage or single-strand breaks occur much more frequently, DNA double strand breaks are considered the main toxic lesion by which ionizing radiation kills cells. Swift recognition and repair of DNA damage is crucial for affected cells; failure to repair may result in cell death, and misrepair may lead to an accumulation of mutations and genomic instability [38]. Therefore, most cells employ an intricate DNA damage signaling network (Figure 1). Within this network, the ataxia teleangiectasia mutated (ATM) serine/threonine kinase is one of the central regulatory proteins [39, 40]. It is recruited to sites of DNA damage by the Mre11Rad50-Nbs1 DNA-binding complex, and phosphorylates various downstream components, including Chk2 protein and the histone variant $\mathrm{H} 2 \mathrm{AX}$ [41]. These factors in turn recruit other downstream factors, resulting in massive signal amplification and finally in the recruitment of the components of key DNA repair pathways [39].

\section{DNA double strand break repair}

Upon irradiation, DNA double strand breaks occur either directly or as a consequence of two closely located SSBs on opposite strands. As they may lead to the loss of crucial genomic information, their quick and efficient repair is important for cellular integrity and survival. Cellular repair of DNA double strand breaks is carried out by two major pathways, termed non-homologous end joining (NHEJ) and homologous recombination (HR) (Figure 2) [38, 42]. HR requires the presence of a sister chromatid and can therefore only take place during late $\mathrm{S}$ and G2 phases of the cell cycle; therefore, the majority of DNA double strand break repair is commonly carried out by the NHEJ pathway [43]. As an initial step of NHEJ, the strand break is recognized and labeled by the heterodimeric $\mathrm{Ku}$ protein complex $[44,45] . \mathrm{Ku}$ in turn binds and thereby recruits the DNA-dependent protein kinase catalytic subunit (DNA-PKcs) to sites of double strand breaks [46]. DNA-PKcs has weak kinase activity and upon recruitment, can autophosphorylate and also phosphorylate a variety of other repair factors [47]. Clean double strand breaks without overhangs or modified strand ends can then be ligated and are accurately repaired by the NHEJ pathway [42]. However, break ends with additional radiation-induced modifications usually require end processing prior to re-ligation in order to remove other forms of DNA lesions and non-ligatable groups. In a last step, gaps that are created by end processing are filled in by DNA polymerases $\mu$ and $\lambda$, before the X4L4 protein complex consisting of DNA ligase IV and XRCC4 carries 


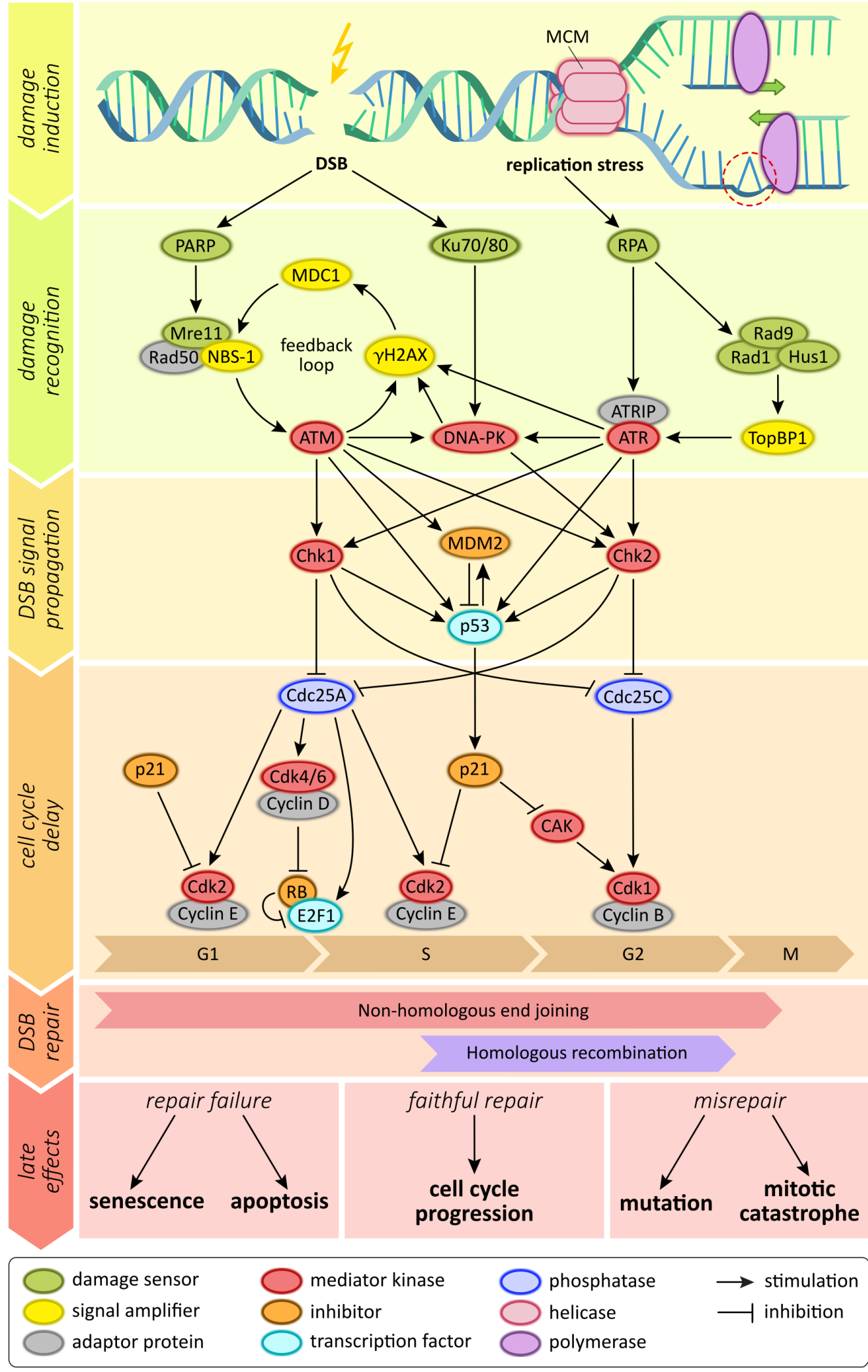

Figure 1: Schematic depiction of signaling molecules and pathways involved in the sensing of DNA double strand breaks. 
out the ligation step with the support of additional proteins like Cernunnos [42, 48-50]. Depending on the amount of additional damage or modifications at strand ends, removal of damaged sequences during NHEJ may result in the loss of a significant amount of genetic material and therefore often results in error-prone repair.

In contrast, the HR repair pathway carries out conservative DNA double strand break repair by using the sister chromatid as a template. The initial sensing of the strand break as a prerequisite for $\mathrm{HR}$ requires the proteins Mre11, Rad50 and Nbs1 that form a functional unit termed the MRN complex [51-53]. These MRN complexes assemble at both strand ends and recruit the key serine/ threonine protein kinase Ataxia teleangiectasia mutated (ATM) which in turn phosphorylates multiple downstream proteins involved in the double strand break repair [54]. Similar to NHEJ, strand end processing is carried out during HR by several proteins including Exo1, BLM and BRCA1, and single strand ends are created [55-57]. The strand ends are then coated by Rad51 protein multimers which are believed to help detecting areas of homology on the sister chromatid $[58,59]$. The Rad51-coated strand then invades the sister chromatid, and strand elongation is performed by DNA polymerases $\eta$ or $\delta$ from the 3 ' end $[60,61]$. Upon completion of the template-based strand elongation, the repaired strand is either displaced from the duplex DNA and re-annealed, or requires resolution, as the second broken strand may also be captured by the homologous sequence, forming a double Holliday junction [62]. The final ligation is then performed by DNA ligase I [63].

\section{INFLUENCE OF IONIZING RADIATION ON MSCS}

The radiation response of MSCs has been analyzed both in mouse and human cell samples; several studies using high-dose irradiation have demonstrated that the

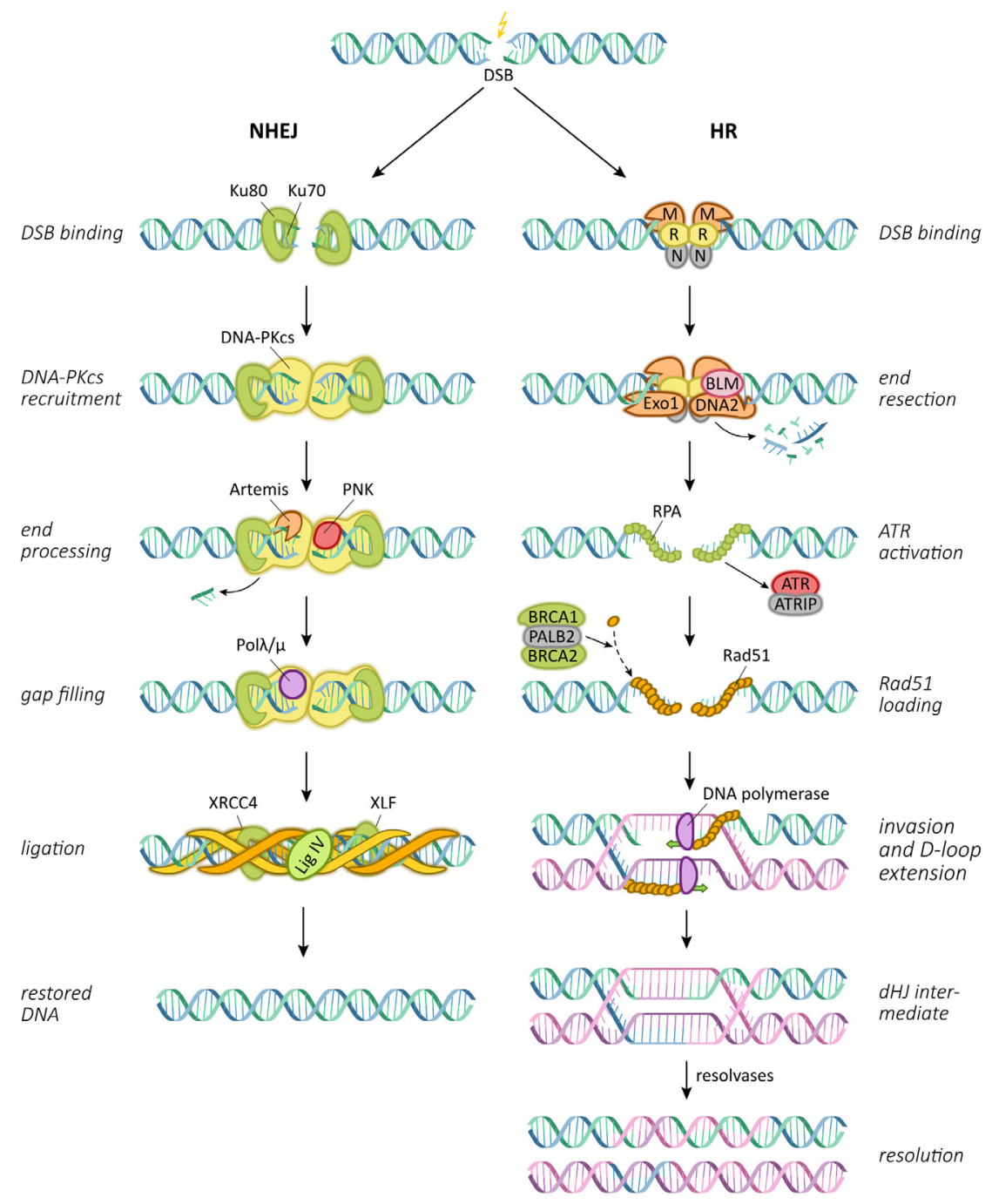

Figure 2: Central pathways and proteins involved in the repair of radiation-induced DNA double strand breaks. NHEJ: non-homologous end joining; DSB: double strand break; HR: homologous recombination; dHJ: double Holliday junction. 
Table 1: The influence of irradiation on key components of the DNA damage signaling and repair pathways in mesenchymal stem cells.

\begin{tabular}{|c|c|c|}
\hline Protein & Function in irradiated MSCS & References \\
\hline \multirow{4}{*}{ ATM } & High baseline levels & {$[12]$} \\
\cline { 2 - 3 } & Strong autophosphorylation after photon irradiation & {$[75,82,83]$} \\
\cline { 2 - 3 } & Strong autophosphorylation after 12C irradiation & {$[75]$} \\
\cline { 2 - 3 } & Strong phosphorylation of downstream targets Chk2, p53 and RPA & {$[79,82,84]$} \\
\cline { 2 - 3 } & Regulation of G2 cell cycle arrest & {$[12,65,75,86]$} \\
\hline \multirow{2}{*}{ Chk2 } & High baseline levels & {$[12]$} \\
\hline DNA-PKcs & Increased phosphorylation & {$[79,82]$} \\
\hline Ku70 & Strong autophosphorylation & {$[79]$} \\
\hline \multirow{2}{*}{ P53 } & Increase of nuclear levels & {$[82]$} \\
\cline { 2 - 3 } & Strong induction & {$[87]$} \\
\hline \multirow{2}{*}{ P21 } & Stabilization & {$[88]$} \\
\cline { 2 - 3 } & Strong induction & \\
\hline
\end{tabular}

in-vitro survival of MSCs was considerably higher than that of other bone marrow-derived stem cells and was similar to other rather radio-resistant cell lines [6466]. Another analysis demonstrated increased radiation resistance of adult human MSCs compared to embryonic stem cells [67]. The described radio-resistance was found to be even more pronounced when MSCs were exposed to fractionated or even hyperfractionated courses of irradiation with single doses ranging between 0.5 and 2 Gy $[68,69]$. Exposure to low-dose radiation was reported to result in increased proliferation of cultured rat MSCs, and even radiation doses as low as 0.01 Gy were found to influence expression patterns of genes involved in DNA replication, stress response, DNA repair and translation initiation [70,71]. The reported relative radiation resistance of MSCs was found more pronounced in hypoxic conditions with hypoxic mouse MSCs showing increased proliferation, increased DNA damage repair and improved long-term survival after exposure to ionizing radiation [72]. Similar to the reported in-vivo data, the radioresistance of MSC has also been shown in vivo: MSCs extracted from porcine mandibular bones after irradiation with single doses up to 18 Gy retained their ability to proliferate and were still able to differentiate along the osteogenic and adipogenic lineages [73].

While most of the published data examined the effects of conventional photon radiotherapy on the stem cells, only few data are available on other forms of ionizing radiation, including proton or heavy-ion treatments. Understanding particle radiobiology becomes more and more important because ions such as protons and carbon ions are increasingly being studied in clinical facilities worldwide for the radiotherapy of cancers, but also in the context of manned space flights, as particle radiation is highly prevalent in deep space and remains a major obstacle for space flights. Experiments using ion radiation in MSCs showed that doses of ${ }^{56} \mathrm{Fe}$ ions up to $1 \mathrm{~Gy}$ were found to lead to more pronounced G2/M phase arrest than physically equivalent photon doses [74]. Another study examining biologically equivalent doses showed that MSCs were similarly resistant to high doses of ${ }^{12} \mathrm{C}$ carbon ion and photon irradiation and retained their stem cell features after both forms of ionizing radiation [75].

The defining stem cell properties of MSCs were shown to be largely intact after exposure to ionizing radiation. The ability of MSCs to swiftly adhere to plastic surfaces and migrate appeared unaffected, and the characteristic adipogenic, osteogenic and chondrogenic differentiation potential could not be abolished by ionizing radiation, although there have been suggestions about a dose-dependent reduction at very high single doses exceeding 10 Gy $[65,76,77]$. Conversely, the differentiation level was demonstrated to influence the radiation response of MSCs, albeit with somewhat contradictory findings: While differentiation along the adipogenic and osteogenic lineages was found to render MSCs more sensitive to ionizing radiation, another study showed that differentiation-restricted, high passagenumber cells seemed to be more resistant compared to their pluripotent, low passage-number counterparts [78, 79].

\section{Activation of DNA damage recognition pathways in MSCs}

Various publications analyzed potential mechanisms underlying the relative radio-resistance of MSCs and have suggested a strong influence of the known DNA damage recognition pathways. As described above, the serine/ threonine kinase ATM is a crucial factor responsible for the recruitment and activation of multiple downstream DNA damage sensing and repair proteins and the initiation of the HR repair pathway; deficiency in ATM function results in increased radiosensitivity [80, 81]. The importance of ATM signaling for the radiation response 
of MSCs was underlined by several studies (Table 1): Expression analyses in mouse stem cell samples found high constitutive expression levels of ATM and the downstream kinase $\mathrm{Chk} 2$ with and without radiation treatment [12]. While ATM expression was reported to be stable even after very high radiation doses of up to 60 Gy, irradiation of MSCs both with low and high photon doses and ${ }^{12} \mathrm{C}$ particles was observed to strongly increase ATM autophosphorylation and activation [75, 82, 83]. However, small-molecule inhibition of ATM in MSCs did not abrogate accumulation in G2 phase of the cell cycle, suggesting compensatory pathways, likely involving the key NHEJ kinase DNA-PKcs [84]. Several regulatory proteins have been observed to be phosphorylated in an ATM-dependent fashion in MSCs, including p53, Chk2 and replication protein A $[79,82,84]$. Knockdown of the ATM-dependent downstream kinases Chk1 and Chk2 was reported to increase radiosensitivity of MSCs as measured by residual DNA double strand breaks and increased levels of apoptosis [85]. Besides the ATM pathway, the function of DNA-PKcs was found to be comparably important for the DNA damage signaling of MSCs, and prolonged phosphorylation of DNA-PKcs was observed in stem cells with unrepaired DNA double strand breaks [79, 82]. The damage signaling patterns reported in MSCs suggest that both DNA double strand break repair pathways play an important role in the radiation response of these cells.

Additionally, expression analyses in MSCs reported a strong induction of the cell cycle-regulating proteins p53 and p21 by ionizing radiation [82]. Activation of the damage signaling pathways was found to result in transient delays in $\mathrm{G} 1 / \mathrm{S}, \mathrm{S}$ or $\mathrm{G} 2 / \mathrm{M}$ phases of the cell cycle. It has been shown that the ATM-dependent pathway activation was able to induce cell cycle arrests both in mouse and in human MSCs. While the observed effects in mouse cell lines were weak and transient, the arrest described in human samples was more pronounced and appeared both in $\mathrm{G} 1 / \mathrm{M}$ and $\mathrm{G} 2$ phases $[12,65,86]$. This observation has been attributed to a stabilization of $\mathrm{p} 53$ and prolonged expression of the downstream protein p21 in irradiated human MSCs [87, 88].

\section{DNA damage repair capacities of MSCs}

As outlined above, DNA double strand breaks as the critical radiation-induced lesions are commonly repaired by the HR and NHEJ pathways, dependent on the cellular repair capacity and the cell cycle phase. Several studies analyzed the activity of DNA double strand break repair in MSCs and found efficient repair of these lesions after irradiation as measured by phosphorylated histone H2AX $(\gamma \mathrm{H} 2 \mathrm{AX})$ levels $[79,82,87,89]$. Even following high doses of photon or ${ }^{12} \mathrm{C}$ particle radiation, MSCs were found to efficiently repair DNA double strand breaks within 24 hours [75]. This swift repair seems to be mediated by both the NHEJ and the HR pathways: Upon exposure to ionizing radiation, the quick but potentially error-prone NHEJ pathway was found to be strongly activated in MSCs; and blockade of the NHEJ pathway by chemical inhibition of DNA-PKcs reportedly resulted in lower numbers of initial $\gamma \mathrm{H} 2 \mathrm{AX}$ foci but increased residual levels at 24 hours, suggesting a higher ratio of unrepaired double strand breaks [64, 82]. Additionally, nuclear Ku70 levels were found to increase in MSCs after irradiation, an effect that was even more pronounced when MSCs underwent adipogenic or osteogenic differentiation [79]. While the NHEJ nuclease DCLRE1C/Artemis was shown to prevent genomic damage in MSCs after exposure to ionizing radiation, it seemed dispensable for the radiationdependent survival of MSCs, and DCLRE1C-deficient cells were found to be even more radioresistant than their functional counterparts [90]. In this context it has been proposed that a deficiency in the NHEJ pathway may introduce a "paraneoplastic" MSC phenotype.

Besides NHEJ repair, the dependence of MSCs on the HR pathway for the repair of radiation-induced double strand breaks has also been demonstrated. Inhibition of ATM in irradiated MSCs resulted in increased residual $\mathrm{H} 2 \mathrm{AX}$ foci levels, demonstrating a dependence of these stem cells on the initiation of HR [82]. However, the ATM blockade did not abrogate H2AX phosphorylation or cell cycle arrest, suggesting an interplay between HR and NHEJ in irradiated MSCs [84]. Experiments using mouse MSCs deficient in the Fanconi anemia group protein FANCD2 showed that those cells were more radiosensitive to ionizing radiation, underpinning the importance of homology-directed double strand break repair [91]. Hypoxic MSCs were found to be even more proficient in the HR repair of radiation-induced DNA double strand breaks, as Rad51 was shown to be regulated by the hypoxia-inducible factor $1 \alpha(\operatorname{HIF} 1 \alpha)[72,92]$.

\section{The effects of ionizing radiation on MSC apoptosis, senescence and autophagy}

Upon induction of irreparable DNA damage by ionizing radiation, cellular mechanisms such as apoptosis, senescence or autophagy have been described for a variety of cell types. Several studies have analyzed the induction of apoptosis in MSCs after irradiation. Doses up to 20 Gy were observed to only result in minimal induction of cellular apoptosis $[64,65,75,84,86,93]$. These findings were supported by expression analyses of MSCs, demonstrating high expression levels of anti-apoptotic proteins BCL-2 and BCL-XL, while only low levels of pro-apoptotic proteins such as Puma were reported for these cells $[12,87]$.

In contrast, cellular senescence has been shown to strongly increase upon exposure of MSCs to ionizing radiation and has been hypothesized to be the main coping mechanism by which MSCs avoid proliferation 
after severe genomic damage [84, 94]. Radioresistant MSCs populations were found to exhibit both strong $\beta$-galactosidase activity and an increased expression of the cyclin-dependent kinase inhibitor 2A (p16-INK4A) at late time points after irradiation with doses up to 60 Gy $[83,84]$. Additionally, treatment with low radiation doses between 0.04 Gy and 2 Gy was observed to result in increased levels of senescence without affecting apoptosis [93]. Induction of senescence in MSCs was found to be mediated by both the retinoblastoma protein, $\mathrm{pRB}$, and the tumor suppressor, p53 [95, 96]. The senescence of MSCs induced by high doses of IR resulted in reduced osteogenic and adipogenic differentiation potentials [96]. Additionally, the reorganization of the MSC cytoskeletal architecture as regulated by the protein kinase CK2 has been suggested as a result of radiation-induce senescence, although other publications did not find an influence of irradiation on the MSC cytoskeleton [65, 97]. On a molecular level, typical senescence-associated DNA methylation changes were found to be missing in irradiated MSCs, suggesting a potential evasion mechanism contributing to the reported radiation resistance of these cells [98].

To date, there is only little evidence for the role of autophagy in irradiated MSCs, and the published data are somewhat contradictory. One study reported a reduction in the autophagy levels after both high and low-dose irradiation, suggesting a decreased ability to remove damaged cellular components [99]. Other publications have discussed autophagy as another means by which MSCs prevent radiation injury. The induction of autophagy in MSCs was shown to lead to reduced levels of radiationinduced reactive oxygen species (ROS), resulting in the preservation of the cellular differentiation potential and the expression of stem cell markers $[100,101]$. Autophagy was observed to be increased in MSCs by hypoxia via activation of the ERK1/2 and mTOR pathways, linking with previous findings that hypoxia could increase MSC radioresistance [72, 102, 103].

\section{Heterogeneity of the MSC radiation resistance}

MSCs seem to comprise a heterogeneous cellular population and are therefore often termed multipotent mesenchymal stromal cells to differentiate them from other clonal stem cells of the bone marrow. Comparative analyses reported varying levels of radioresistance in human and mouse MSCs derived from different organ sites [86, 104]. Additionally, several publications have suggested that each MSC pool contains only a certain subpopulation with stem cell characteristics which defines the stem cell-like properties of this cell type rather than the whole pool forming a stem cell population $[3,105-108]$. Therefore, it has been proposed that the observed radioresistant phenotype may also be due to a radioresistant subpopulation of MSCs, as has been reported for cancer-initiating cells. However, only limited experimental data back up this hypothesis [83, 99]. Data published on the effects of high-dose radiation with 30 and 60 Gy on MSCs identified a highly radioresistant MSC subpopulation within the tested cell pool that not only survived the treatment, but also kept the ability for tri-lineage differentiation [83]. The characterized MSCs were found to keep their surface marker expression but had altered secretion profiles of VEGF and PDGF and became prematurely senescent. In this context, the level of "stemness" and the role of certain MSCs as precursors of other partially restricted MSCs have been discussed [87, 104]. However, several other publications report strong radioresistance effects from pooled MSC populations, and those findings are difficult to be attributed to only a small sub-group of these cells $[12,64,65]$. Therefore, further efforts are needed to clearly identify radioresistant subpopulations within the MSC population.

\section{POTENTIAL APPLICATIONS AND CHALLENGES OF RADIORESISTANT MSCS}

\section{Repair of radiation-induced tissue damage}

The role of MSCs in the repair of various forms of tissue damage has been well established both in vitro and in animal models, especially in the context of mechanical and ischemic lesions [34, 35, 109-114]. Regarding the demonstrated radiation resistance of MSCs, these cells may also have a role in the regeneration of organ damage induced by ionizing radiation. Apart from the involvement of the body's own MSCs in the repair of radiation damage that remains largely elusive, potential benefits of both treatment with autologous MSCs and allogeneic infusions of MSCs have been widely studied in vitro and in animal models. MSC infusions after irradiation of different organs with lethal or sub-lethal doses resulted in improved overall survival in several datasets [115-120]. However, it has been suggested that beneficial effects of MSC-based treatments were dependent on the timing of infusions and cell numbers [121]. The exact underlying mechanisms for the MSCs' radioprotective effects are yet to be established. Radiotherapy was widely found to induce both the homing and the engraftment of transplanted MSCs in radiationdamaged organs in rat and mouse models [122-127]. Further examinations demonstrated detectable levels of allogeneic GFP-labeled MSCs in radiation-damaged tissue samples up to 80 days after infusion [128]. However, other analyses reported only transient invasion of MSCs, and it has been suggested that their beneficial effect may be attributable to paracrine effects or the programming of other involved cell types [129]. This finding has been backed up by the observation that treatment of irradiated 
animals with MSC-conditioned media mimicked the increased repair of radiation damage [130]. Generally, the generation of clear data regarding mechanistic aspects of MSC-mediated repair of tissue radiation damage has been somewhat hampered by the lack of generally accepted surface markers, which would help to detect MSCs in damaged tissues and clearly attribute observed effects to these cells $[7,87]$. Beyond the data generated from animal models, first MSC-based therapies in humans treated for acute radiation injuries, mostly on the grounds of compassionate use, have revealed clinical benefits regarding the regeneration of hematopoiesis and radiationinduced intestinal inflammation and hemorrhages [131, 132]. Additionally, a Russian trial of 11 patients treated for radiation-induced pulmonary damage showed moderate improvements of breathing parameters, immune functions and tissue hypoxia by MSC infusions [133]. However, stringent clinical trials are required to properly establish potential clinical benefits of MSC-based treatments for radiation injuries. Additionally, the role of the body's own stem cells in the repair of radiation-induced and the development of radiation side effects remains largely unknown. Nevertheless, if MSCs are verified to attribute to the regeneration of radiation-induced tissue damage, their potential impact may affect diverse fields including medical procedures, radiation protection efforts and space flight endeavors. Beyond the alleviation of radiation treatment-related side effects, MSCs may have the potential to evolve as a means to support radiation protection efforts in the event of a nuclear radiation disaster or in the context of tackling the cosmic radiation risk for space flights, where large experimental programs are currently underway to study their biological effects [134-137].

\section{Radioprotection of tumor tissues}

As outlined above, MSCs have been accredited with exhibiting radioprotective and regenerative functions in normal tissues exposed to ionizing radiation. Therefore, it is possible that they may similarly exert their effects on tumors treated with radiotherapy. However, there is a lack of published in-vivo data regarding the influence of MSCs on the radioprotection or regeneration of cancer tissue exposed to ionizing radiation. In an in-vitro study, breast cancer cells were found to exhibit increased proliferation rates and radioresistance by treatment with MSC-conditioned medium, an effect attributed to the high levels of insulin-like growth factor-1 within the medium [138]. Despite the fact that no in-vivo data have been published to back up this finding, there is still a potential risk that radiotherapy itself increases the radiation resistance of cancer tissues by increasing the attraction and engraftment of MSCs into the irradiated tumor microenvironment. Data obtained from irradiated mice demonstrated that low dose radiation treatment resulted in increased invasion of MSCs from the perivascular into the parenchymal areas of tumors and increased secretion of the cytokines, PDGF, VEGF and TGF $\beta$ [139]. Additionally, several publications have shown the angiogenic potential of MSC-based treatments, and MSC infusions were found to increase angiogenesis in ischemic tissues [140-144]. The impact of the MSCs' angiogenic properties on the tumor response to radiotherapy has been subject to some discussions. While it may be possible that these stem cells can counteract antiangiogenic tumor therapies, it is likewise conceivable that they may improve the oxygen supply to tumor tissues, thereby increasing the radiosensitivity of irradiated cancers. It has been shown that MSC proliferation is dependent on proangiogenic signaling molecules such as VEGF, and VEGF inhibition severely radiosensitized MSCs in vitro [66]. While it can be speculated that MSCs may exert some radioprotective effects on tumors cells, in-vivo data are lacking. However, if these speculations are backed up by experimental findings, the dose-dependent increase in intratumoral migration of MSCs may pose additional problems due to the fact that MSCs themselves are radioresistant and may not be properly targeted by the radiation treatment. Coculture data provided some evidence for the creation of an inflammatory microenvironment, resulting in an impaired sensitivity to anti-cancer treatments and ultimately in the promotion of tumor growth and an increased risk of tumor recurrence [145]. To rule out potential radioprotective effects of MSCs on irradiated tumors, solid in-vivo data are needed that take into account the effects of MSCs on the microenvironment and their interaction with other cell types of the tumor stroma. These data are a prerequisite for establishing any form of MSC-based therapy for radiationinduced tissue damage in the clinical routine.

\section{SUMMARY}

The influence of ionizing radiation on adult mesenchymal stem cells has been extensively examined. It has been well established that MSCs exhibit a radioresistant phenotype and are able to retain their defining stem cell properties after exposure to high radiation doses. The published research indicates that MSCs are able to quickly and efficiently recognize radiation-induced DNA damage via different recognition pathways. Additionally, a strong activity of both DNA double strand break repair pathways, homologous recombination and non-homologous end joining, has been linked to the described radioresistant phenotype of MSCs. High expression levels of anti-apoptotic proteins result in the cells' evasion of apoptosis even after high doses of ionizing radiation, while the role of senescence and autophagy requires further examination. Due to their radioresistant phenotype, MSCs may qualify as a therapeutic means to treat radiation-induced tissue damage. However, potential protective effects on 
irradiated tumors require further research into this cell type, before MSC-based therapies will find their way into the clinic for the treatment of radiation-induced tissue damage.

\section{ACKNOWLEDGMENTS}

This work was supported by a young investigator grant of the Heidelberg University Faculty of Medicine to N.H.N. All authors state that there is no conflict of interest.

\section{CONFLICTS OF INTEREST}

there is no conflict of interest.

\section{REFERENCES}

1. Friedenstein AJ, Deriglasova UF, Kulagina NN, Panasuk AF, Rudakowa SF, Luria EA and Ruadkow IA. Precursors for fibroblasts in different populations of hematopoietic cells as detected by the in vitro colony assay method. Experimental hematology. 1974; 2:83-92.

2. Morikawa S, Mabuchi Y, Kubota Y, Nagai Y, Niibe K, Hiratsu E, Suzuki S, Miyauchi-Hara C, Nagoshi N, Sunabori T, Shimmura S, Miyawaki A, Nakagawa T, Suda T, Okano H and Matsuzaki Y. Prospective identification, isolation, and systemic transplantation of multipotent mesenchymal stem cells in murine bone marrow. The Journal of experimental medicine. 2009; 206:2483-2496.

3. Ho AD, Wagner $\mathrm{W}$ and Franke W. Heterogeneity of mesenchymal stromal cell preparations. Cytotherapy. 2008; 10:320-330

4. Chen BY, Wang X, Chen LW and Luo ZJ. Molecular targeting regulation of proliferation and differentiation of the bone marrow-derived mesenchymal stem cells or mesenchymal stromal cells. Curr Drug Targets. 2012; 13:561-571.

5. Tolar J, Le Blanc K, Keating A and Blazar BR. Concise review: hitting the right spot with mesenchymal stromal cells. Stem cells. 2010; 28:1446-1455.

6. Pittenger MF, Mackay AM, Beck SC, Jaiswal RK, Douglas R, Mosca JD, Moorman MA, Simonetti DW, Craig S and Marshak DR. Multilineage potential of adult human mesenchymal stem cells. Science. 1999; 284:143-147.

7. Dominici M, Le Blanc K, Mueller I, Slaper-Cortenbach I, Marini F, Krause D, Deans R, Keating A, Prockop D and Horwitz E. Minimal criteria for defining multipotent mesenchymal stromal cells. The International Society for Cellular Therapy position statement. Cytotherapy. 2006; 8:315-317.

8. Murray IR, West CC, Hardy WR, James AW, Park TS, Nguyen A, Tawonsawatruk T, Lazzari L, Soo C and Peault B. Natural history of mesenchymal stem cells, from vessel walls to culture vessels. Cellular and molecular life sciences
: CMLS. 2014; 71:1353-1374.

9. Parolini O, Alviano F, Bagnara GP, Bilic G, Buhring HJ, Evangelista M, Hennerbichler S, Liu B, Magatti M, Mao N, Miki T, Marongiu F, Nakajima H, Nikaido T, PortmannLanz CB, Sankar V, et al. Concise review: isolation and characterization of cells from human term placenta: outcome of the first international Workshop on Placenta Derived Stem Cells. Stem cells. 2008; 26:300-311.

10. Levi B and Longaker MT. Concise review: adipose-derived stromal cells for skeletal regenerative medicine. Stem cells. 2011; 29:576-582.

11. Morrison SJ and Scadden DT. The bone marrow niche for haematopoietic stem cells. Nature. 2014; 505:327-334.

12. Sugrue T, Brown JA, Lowndes NF and Ceredig R. Multiple Facets of The DNA Damage Response Contribute to the Radio-Resistance of Mouse Mesenchymal Stromal Cell Lines. Stem cells. 2012.

13. Wang LD and Wagers AJ. Dynamic niches in the origination and differentiation of haematopoietic stem cells. Nature reviews Molecular cell biology. 2011; 12:643-655.

14. Ehninger A and Trumpp A. The bone marrow stem cell niche grows up: mesenchymal stem cells and macrophages move in. The Journal of experimental medicine. 2011; 208:421-428.

15. Chow A, Lucas D, Hidalgo A, Mendez-Ferrer S, Hashimoto D, Scheiermann C, Battista M, Leboeuf M, Prophete C, van Rooijen N, Tanaka M, Merad M and Frenette PS. Bone marrow CD169+ macrophages promote the retention of hematopoietic stem and progenitor cells in the mesenchymal stem cell niche. The Journal of experimental medicine. 2011; 208:261-271.

16. Schraufstatter IU, Discipio RG and Khaldoyanidi $\mathrm{S}$. Mesenchymal stem cells and their microenvironment. Frontiers in bioscience. 2011; 16:2271-2288.

17. Anthony BA and Link DC. Regulation of hematopoietic stem cells by bone marrow stromal cells. Trends in immunology. 2014; 35:32-37.

18. Li T and $\mathrm{Wu} \mathrm{Y}$. Paracrine molecules of mesenchymal stem cells for hematopoietic stem cell niche. Bone marrow research. 2011; 2011:353878.

19. Sinclair K, Yerkovich ST and Chambers DC. Mesenchymal stem cells and the lung. Respirology. 2013; 18:397-411.

20. Gomez-Gaviro MV, Lovell-Badge R, Fernandez-Aviles F and Lara-Pezzi E. The vascular stem cell niche. Journal of cardiovascular translational research. 2012; 5:618-630.

21. Liu H, Zhang J, Liu CY, Hayashi Y and Kao WW. Bone marrow mesenchymal stem cells can differentiate and assume corneal keratocyte phenotype. Journal of cellular and molecular medicine. 2012; 16:1114-1124.

22. Nedeau AE, Bauer RJ, Gallagher K, Chen H, Liu ZJ and Velazquez OC. A CXCL5- and bFGF-dependent effect of PDGF-B-activated fibroblasts in promoting trafficking and differentiation of bone marrow-derived mesenchymal stem cells. Experimental cell research. 2008; 314:2176-2186. 
23. Kalinina NI, Sysoeva VY, Rubina KA, Parfenova YV and Tkachuk VA. Mesenchymal stem cells in tissue growth and repair. Acta Naturae. 2011; 3:30-37.

24. Ulivi V, Tasso $R$, Cancedda $R$ and Descalzi $F$. Mesenchymal stem cell paracrine activity is modulated by platelet lysate: induction of an inflammatory response and secretion of factors maintaining macrophages in a proinflammatory phenotype. Stem cells and development. 2014; 23:1858-1869.

25. Mendez-Ferrer S, Michurina TV, Ferraro F, Mazloom AR, Macarthur BD, Lira SA, Scadden DT, Ma'ayan A, Enikolopov GN and Frenette PS. Mesenchymal and haematopoietic stem cells form a unique bone marrow niche. Nature. 2010; 466:829-834.

26. Mayer H, Bertram H, Lindenmaier W, Korff T, Weber $\mathrm{H}$ and Weich $\mathrm{H}$. Vascular endothelial growth factor (VEGF-A) expression in human mesenchymal stem cells: autocrine and paracrine role on osteoblastic and endothelial differentiation. Journal of cellular biochemistry. 2005; 95:827-839.

27. Kim DH, Yoo KH, Choi KS, Choi J, Choi SY, Yang SE, Yang YS, Im HJ, Kim KH, Jung HL, Sung KW and Koo HH. Gene expression profile of cytokine and growth factor during differentiation of bone marrow-derived mesenchymal stem cell. Cytokine. 2005; 31:119-126.

28. Bae SH, Ryu H, Rhee KJ, Oh JE, Baik SK, Shim KY, Kong JH, Hyun SY, Pack HS, Im C, Shin HC, Kim YM, Kim HS, Eom YW and Lee JI. 1-Ascorbic acid 2-phosphate and fibroblast growth factor-2 treatment maintains differentiation potential in bone marrow-derived mesenchymal stem cells through expression of hepatocyte growth factor. Growth Factors. 2015; 33:71-78.

29. Liu $\mathrm{CH}$ and Hwang SM. Cytokine interactions in mesenchymal stem cells from cord blood. Cytokine. 2005; 32:270-279.

30. Fang X, Neyrinck AP, Matthay MA and Lee JW. Allogeneic human mesenchymal stem cells restore epithelial protein permeability in cultured human alveolar type II cells by secretion of angiopoietin-1. The Journal of biological chemistry. 2010; 285:26211-26222.

31. Lopatina T, Bruno S, Tetta C, Kalinina N, Porta M and Camussi G. Platelet-derived growth factor regulates the secretion of extracellular vesicles by adipose mesenchymal stem cells and enhances their angiogenic potential. Cell communication and signaling : CCS. 2014; 12:26.

32. Lopatina T, Kalinina N, Karagyaur M, Stambolsky D, Rubina K, Revischin A, Pavlova G, Parfyonova Y and Tkachuk V. Adipose-derived stem cells stimulate regeneration of peripheral nerves: BDNF secreted by these cells promotes nerve healing and axon growth de novo. PloS one. 2011; 6:e17899.

33. Jo CH, Lee YG, Shin WH, Kim H, Chai JW, Jeong EC, Kim JE, Shim H, Shin JS, Shin IS, Ra JC, Oh S and Yoon KS. Intra-articular injection of mesenchymal stem cells for the treatment of osteoarthritis of the knee: a proof-of- concept clinical trial. Stem cells. 2014; 32:1254-1266.

34. Wilson JG, Liu KD, Zhuo H, Caballero L, McMillan M, Fang X, Cosgrove K, Vojnik R, Calfee CS, Lee JW, Rogers AJ, Levitt J, Wiener-Kronish J, Bajwa EK, Leavitt A, McKenna D, et al. Mesenchymal stem (stromal) cells for treatment of ARDS: a phase 1 clinical trial. The Lancet Respiratory medicine. 2015; 3:24-32.

35. Zhang Y, Liang X, Lian Q and Tse HF. Perspective and challenges of mesenchymal stem cells for cardiovascular regeneration. Expert review of cardiovascular therapy. 2013; 11:505-517.

36. Mahaney BL, Meek K and Lees-Miller SP. Repair of ionizing radiation-induced DNA double-strand breaks by non-homologous end-joining. Biochem J. 2009; 417:639650 .

37. Goodhead DT. Initial events in the cellular effects of ionizing radiations: clustered damage in DNA. International journal of radiation biology. 1994; 65:7-17.

38. Helleday T, Petermann E, Lundin C, Hodgson B and Sharma RA. DNA repair pathways as targets for cancer therapy. Nature reviews Cancer. 2008; 8:193-204.

39. Shiloh Y and Ziv Y. The ATM protein kinase: regulating the cellular response to genotoxic stress, and more. Nature reviews Molecular cell biology. 2013; 14:197-210.

40. Tomita M. Involvement of DNA-PK and ATM in radiationand heat-induced DNA damage recognition and apoptotic cell death. Journal of radiation research. 2010; 51:493-501.

41. Solier S, Sordet O, Kohn KW and Pommier Y. Death receptor-induced activation of the Chk2- and histone H2AX-associated DNA damage response pathways. Molecular and cellular biology. 2009; 29:68-82.

42. Wu PY, Frit P, Malivert L, Revy P, Biard D, Salles B and Calsou P. Interplay between Cernunnos-XLF and nonhomologous end-joining proteins at DNA ends in the cell. The Journal of biological chemistry. 2007; 282:3193731943.

43. Branzei D and Foiani M. Regulation of DNA repair throughout the cell cycle. Nature reviews Molecular cell biology. 2008; 9:297-308.

44. Chen F, Peterson SR, Story MD and Chen DJ. Disruption of DNA-PK in Ku80 mutant xrs-6 and the implications in DNA double-strand break repair. Mutation research. 1996; 362:9-19.

45. Jin S and Weaver DT. Double-strand break repair by Ku70 requires heterodimerization with $\mathrm{Ku} 80$ and DNA binding functions. The EMBO journal. 1997; 16:6874-6885.

46. Schild-Poulter C, Pope L, Giffin W, Kochan JC, Ngsee JK, Traykova-Andonova $\mathrm{M}$ and Hache RJ. The binding of $\mathrm{Ku}$ antigen to homeodomain proteins promotes their phosphorylation by DNA-dependent protein kinase. The Journal of biological chemistry. 2001; 276:16848-16856.

47. Ding Q, Reddy YV, Wang W, Woods T, Douglas $\mathrm{P}$, Ramsden DA, Lees-Miller SP and Meek K. Autophosphorylation of the catalytic subunit of the 
DNA-dependent protein kinase is required for efficient end processing during DNA double-strand break repair. Molecular and cellular biology. 2003; 23:5836-5848.

48. Lee JW, Yannone SM, Chen DJ and Povirk LF. Requirement for XRCC4 and DNA ligase IV in alignmentbased gap filling for nonhomologous DNA end joining in vitro. Cancer research. 2003; 63:22-24.

49. Lee JW, Blanco L, Zhou T, Garcia-Diaz M, Bebenek K, Kunkel TA, Wang $Z$ and Povirk LF. Implication of DNA polymerase lambda in alignment-based gap filling for nonhomologous DNA end joining in human nuclear extracts. The Journal of biological chemistry. 2004; 279:805-811.

50. Nick McElhinny SA, Havener JM, Garcia-Diaz M, Juarez R, Bebenek K, Kee BL, Blanco L, Kunkel TA and Ramsden DA. A gradient of template dependence defines distinct biological roles for family $\mathrm{X}$ polymerases in nonhomologous end joining. Molecular cell. 2005; 19:357366.

51. Williams RS, Moncalian G, Williams JS, Yamada Y, Limbo O, Shin DS, Groocock LM, Cahill D, Hitomi C, Guenther G, Moiani D, Carney JP, Russell P and Tainer JA. Mre11 dimers coordinate DNA end bridging and nuclease processing in double-strand-break repair. Cell. 2008; 135:97-109.

52. Lamarche BJ, Orazio NI and Weitzman MD. The MRN complex in double-strand break repair and telomere maintenance. FEBS letters. 2010; 584:3682-3695.

53. Williams RS, Dodson GE, Limbo O, Yamada Y, Williams JS, Guenther G, Classen S, Glover JN, Iwasaki H, Russell $\mathrm{P}$ and Tainer JA. Nbs1 flexibly tethers Ctp1 and Mre11Rad50 to coordinate DNA double-strand break processing and repair. Cell. 2009; 139:87-99.

54. Iijima K, Ohara M, Seki R and Tauchi H. Dancing on damaged chromatin: functions of ATM and the RAD50/ MRE11/NBS1 complex in cellular responses to DNA damage. Journal of radiation research. 2008; 49:451-464.

55. Ellis NA, Groden J, Ye TZ, Straughen J, Lennon DJ, Ciocci S, Proytcheva M and German J. The Bloom's syndrome gene product is homologous to RecQ helicases. Cell. 1995; 83:655-666.

56. Thompson LH. Recognition, signaling, and repair of DNA double-strand breaks produced by ionizing radiation in mammalian cells: the molecular choreography. Mutation research. 2012; 751:158-246.

57. Coleman KA and Greenberg RA. The BRCA1-RAP80 complex regulates DNA repair mechanism utilization by restricting end resection. The Journal of biological chemistry. 2011; 286:13669-13680.

58. Bianco PR, Tracy RB and Kowalczykowski SC. DNA strand exchange proteins: a biochemical and physical comparison. Frontiers in bioscience : a journal and virtual library. 1998; 3:D570-603.

59. McIlwraith MJ, Van Dyck E, Masson JY, Stasiak AZ,
Stasiak A and West SC. Reconstitution of the strand invasion step of double-strand break repair using human Rad51 Rad52 and RPA proteins. Journal of molecular biology. 2000; 304:151-164.

60. McIlwraith MJ, Vaisman A, Liu Y, Fanning E, Woodgate R and West SC. Human DNA polymerase eta promotes DNA synthesis from strand invasion intermediates of homologous recombination. Molecular cell. 2005; 20:783-792.

61. Sebesta M, Burkovics P, Haracska L and Krejci L. Reconstitution of DNA repair synthesis in vitro and the role of polymerase and helicase activities. DNA repair. 2011; 10:567-576.

62. Hartlerode AJ and Scully R. Mechanisms of double-strand break repair in somatic mammalian cells. The Biochemical journal. 2009; 423:157-168.

63. Goetz JD, Motycka TA, Han M, Jasin M and Tomkinson AE. Reduced repair of DNA double-strand breaks by homologous recombination in a DNA ligase I-deficient human cell line. DNA repair. 2005; 4:649-654.

64. Chen MF, Lin CT, Chen WC, Yang CT, Chen CC, Liao SK, Liu JM, Lu CH and Lee KD. The sensitivity of human mesenchymal stem cells to ionizing radiation. International journal of radiation oncology, biology, physics. 2006; 66:244-253.

65. Nicolay NH, Sommer E, Lopez R, Wirkner U, Trinh T, Sisombath S, Debus J, Ho AD, Saffrich R and Huber PE. Mesenchymal stem cells retain their defining stem cell characteristics after exposure to ionizing radiation. International journal of radiation oncology, biology, physics. 2013; 87:1171-1178.

66. Nicolay NH, Sommer E, Perez RL, Wirkner U, Bostel T, Ho AD, Lahn M, Debus J, Saffrich R and Huber PE. Mesenchymal stem cells are sensitive to treatment with kinase inhibitors and ionizing radiation. Strahlentherapie und Onkologie : Organ der Deutschen Rontgengesellschaft [et al]. 2014; 190:1037-1045.

67. Islam MS, Stemig ME, Takahashi Y and Hui SK. Radiation response of mesenchymal stem cells derived from bone marrow and human pluripotent stem cells. J Radiat Res. 2015; 56:269-77.

68. Clavin NW, Fernandez J, Schonmeyr BH, Soares MA and Mehrara BJ. Fractionated doses of ionizing radiation confer protection to mesenchymal stem cell pluripotency. Plastic and reconstructive surgery. 2008; 122:739-748.

69. Tomuleasa C, Soritau O, Brie I, Pall E, Foris V, Dicu T, Virag P, Irimie A and Kacso G. Mesenchymal stem cell irradiation in culture engages differential effect of hyperfractionated radiotherapy for head and neck cancers. Journal of BUON : official journal of the Balkan Union of Oncology. 2010; 15:348-356.

70. Liang X, So YH, Cui J, Ma K, Xu X, Zhao Y, Cai L and $\mathrm{Li} \mathrm{W}$. The low-dose ionizing radiation stimulates cell proliferation via activation of the MAPK/ERK pathway in rat cultured mesenchymal stem cells. Journal of radiation 
research. 2011; 52:380-386.

71. Jin YW, Na YJ, Lee YJ, An S, Lee JE, Jung M, Kim H, Nam SY, Kim CS, Yang KH, Kim SU, Kim WK, Park WY, Yoo KY, Kim CS and Kim JH. Comprehensive analysis of time- and dose-dependent patterns of gene expression in a human mesenchymal stem cell line exposed to low-dose ionizing radiation. Oncology reports. 2008; 19:135-144.

72. Sugrue T, Lowndes NF and Ceredig R. Hypoxia enhances the radioresistance of mouse mesenchymal stromal cells. Stem cells. 2014; 32:2188-2200.

73. Singh S, Kloss FR, Brunauer R, Schimke M, Jamnig A, Greiderer-Kleinlercher B, Klima G, Rentenberger J, Auberger T, Hachl O, Rasse M, Gassner R and Lepperdinger G. Mesenchymal stem cells show radioresistance in vivo. Journal of cellular and molecular medicine. 2012; 16:877887.

74. Kurpinski K, Jang DJ, Bhattacharya S, Rydberg B, Chu J, So J, Wyrobek A, Li S and Wang D. Differential effects of $\mathrm{x}$-rays and high-energy 56Fe ions on human mesenchymal stem cells. Int J Radiat Oncol Biol Phys. 2009; 73:869-877.

75. Nicolay NH, Liang Y, Lopez Perez R, Bostel T, Trinh T, Sisombath S, Weber KJ, Ho AD, Debus J, Saffrich R and Huber PE. Mesenchymal stem cells are resistant to carbon ion radiotherapy. Oncotarget. 2015; 6:2076-2087.

76. Li J, Kwong DL and Chan GC. The effects of various irradiation doses on the growth and differentiation of marrow-derived human mesenchymal stromal cells. Pediatr Transplant. 2007; 11:379-387.

77. Schonmeyr BH, Wong AK, Soares M, Fernandez J, Clavin $\mathrm{N}$ and Mehrara BJ. Ionizing radiation of mesenchymal stem cells results in diminution of the precursor pool and limits potential for multilineage differentiation. Plastic and reconstructive surgery. 2008; 122:64-76.

78. Mussano F, Lee KJ, Zuk P, Tran L, Cacalano NA, Jewett A, Carossa $\mathrm{S}$ and Nishimura I. Differential effect of ionizing radiation exposure on multipotent and differentiationrestricted bone marrow mesenchymal stem cells. Journal of cellular biochemistry. 2010; 111:322-332.

79. Oliver L, Hue E, Sery Q, Lafargue A, Pecqueur C, Paris F and Vallette FM. Differentiation-related response to DNA breaks in human mesenchymal stem cells. Stem Cells. 2013; 31:800-807.

80. Taylor AM, Harnden DG, Arlett CF, Harcourt SA, Lehmann AR, Stevens S and Bridges BA. Ataxia telangiectasia: a human mutation with abnormal radiation sensitivity. Nature. 1975; 258:427-429.

81. Painter RB and Young BR. Radiosensitivity in ataxiatelangiectasia: a new explanation. Proceedings of the National Academy of Sciences of the United States of America. 1980; 77:7315-7317.

82. Prendergast AM, Cruet-Hennequart S, Shaw G, Barry FP and Carty MP. Activation of DNA damage response pathways in human mesenchymal stem cells exposed to cisplatin or gamma-irradiation. Cell Cycle. 2011; 10:3768-
3777.

83. Fekete N, Erle A, Amann EM, Furst D, Rojewski MT, Langonne A, Sensebe L, Schrezenmeier H and SchmidtkeSchrezenmeier G. Effect of high-dose irradiation on human bone-marrow-derived mesenchymal stromal cells. Tissue engineering Part C, Methods. 2015; 21:112-122.

84. Cmielova J, Havelek R, Soukup T, Jiroutova A, Visek B, Suchanek J, Vavrova J, Mokry J, Muthna D, Bruckova L, Filip S, English D and Rezacova M. Gamma radiation induces senescence in human adult mesenchymal stem cells from bone marrow and periodontal ligaments. Int J Radiat Biol. 2012; 88:393-404.

85. Worku M, Fersht N, Martindale C, Funes JM and Short SC. Sequential transformation of mesenchymal stem cells is associated with increased radiosensitivity and reduced DNA repair capacity. Radiation research. 2013; 179:698-706.

86. Damek-Poprawa M, Stefanik D, Levin LM and Akintoye SO. Human bone marrow stromal cells display variable anatomic site-dependent response and recovery from irradiation. Archives of oral biology. 2010; 55:358-364.

87. Sugrue T, Lowndes NF and Ceredig R. Mesenchymal stromal cells: radio-resistant members of the bone marrow. Immunology and cell biology. 2013; 91:5-11.

88. Mehrara BJ, Avraham T, Soares M, Fernandez JG, Yan A, Zampell JC, Andrade VP, Cordeiro AP and Sorrento CM. p21cip/WAF is a key regulator of long-term radiation damage in mesenchyme-derived tissues. FASEB journal : official publication of the Federation of American Societies for Experimental Biology. 2010; 24:4877-4888.

89. Serakinci N, Christensen R, Graakjaer J, Cairney CJ, Keith WN, Alsner J, Saretzki G and Kolvraa S. Ectopically hTERT expressing adult human mesenchymal stem cells are less radiosensitive than their telomerase negative counterpart. Experimental cell research. 2007; 313:10561067.

90. Maas SA, Donghia NM, Tompkins K, Foreman O and Mills KD. ARTEMIS stabilizes the genome and modulates proliferative responses in multipotent mesenchymal cells. BMC biology. 2010; 8:132.

91. Berhane H, Epperly MW, Goff J, Kalash R, Cao S, Franicola D, Zhang X, Shields D, Houghton F, Wang H, Wipf P, Parmar K and Greenberger JS. Radiologic differences between bone marrow stromal and hematopoietic progenitor cell lines from Fanconi Anemia (Fancd2(-/-)) mice. Radiation research. 2014; 181:76-89.

92. Chaturvedi P, Gilkes DM, Takano N and Semenza GL. Hypoxia-inducible factor-dependent signaling between triple-negative breast cancer cells and mesenchymal stem cells promotes macrophage recruitment. Proceedings of the National Academy of Sciences of the United States of America. 2014; 111:E2120-2129.

93. Alessio N, Del Gaudio S, Capasso S, Di Bernardo G, Cappabianca S, Cipollaro M, Peluso G and Galderisi U. Low dose radiation induced senescence of human 
mesenchymal stromal cells and impaired the autophagy process. Oncotarget. 2015; 6:8155-66.

94. Ko E, Lee KY and Hwang DS. Human umbilical cord blood-derived mesenchymal stem cells undergo cellular senescence in response to oxidative stress. Stem cells and development. 2012; 21:1877-1886.

95. Alessio N, Bohn W, Rauchberger V, Rizzolio F, Cipollaro M, Rosemann M, Irmler M, Beckers J, Giordano A and Galderisi U. Silencing of RB1 but not of RB2/P130 induces cellular senescence and impairs the differentiation potential of human mesenchymal stem cells. Cellular and molecular life sciences : CMLS. 2013; 70:1637-1651.

96. Despars G, Carbonneau CL, Bardeau P, Coutu DL and Beausejour CM. Loss of the osteogenic differentiation potential during senescence is limited to bone progenitor cells and is dependent on p53. PloS one. 2013; 8:e73206.

97. Wang D and Jang DJ. Protein kinase CK2 regulates cytoskeletal reorganization during ionizing radiationinduced senescence of human mesenchymal stem cells. Cancer research. 2009; 69:8200-8207.

98. Koch CM, Reck K, Shao K, Lin Q, Joussen S, Ziegler P, Walenda G, Drescher W, Opalka B, May T, Brummendorf T, Zenke M, Saric T and Wagner W. Pluripotent stem cells escape from senescence-associated DNA methylation changes. Genome research. 2013; 23:248-259.

99. Alessio N, Del Gaudio S, Capasso S, Di Bernardo G, Cappabianca S, Cipollaro M, Peluso G and Galderisi U. Low dose radiation induced senescence of human mesenchymal stromal cells and impaired the autophagy process. Oncotarget. 2015; 6:8155-8166.

100. Hou J, Han ZP, Jing YY, Yang X, Zhang SS, Sun K, Hao C, Meng Y, Yu FH, Liu XQ, Shi YF, Wu MC, Zhang L and Wei LX. Autophagy prevents irradiation injury and maintains stemness through decreasing ROS generation in mesenchymal stem cells. Cell death \& disease. 2013; 4:e844.

101. Song C, Song C and Tong F. Autophagy induction is a survival response against oxidative stress in bone marrowderived mesenchymal stromal cells. Cytotherapy. 2014: S1465-3249(14)00563-5.

102. Wu J, Niu J, Li X, Li Y, Wang X, Lin J and Zhang F. Hypoxia induces autophagy of bone marrow-derived mesenchymal stem cells via activation of ERK1/2. Cellular physiology and biochemistry : international journal of experimental cellular physiology, biochemistry, and pharmacology. 2014; 33:1467-1474.

103. Lee Y, Jung J, Cho KJ, Lee SK, Park JW, Oh IH and Kim GJ. Increased SCF/c-kit by hypoxia promotes autophagy of human placental chorionic plate-derived mesenchymal stem cells via regulating the phosphorylation of mTOR. Journal of cellular biochemistry. 2013; 114:79-88.

104. Carbonneau CL, Despars G, Rojas-Sutterlin S, Fortin A, Le $\mathrm{O}$, Hoang $\mathrm{T}$ and Beausejour $\mathrm{CM}$. Ionizing radiation-induced expression of INK4a/ARF in murine bone marrow-derived stromal cell populations interferes with bone marrow homeostasis. Blood. 2012; 119:717-726.

105. Conese M, Piro D, Carbone A, Castellani S and Di Gioia S. Hematopoietic and mesenchymal stem cells for the treatment of chronic respiratory diseases: role of plasticity and heterogeneity. TheScientificWorldJournal. 2014; 2014:859817.

106. Sivasubramaniyan K, Lehnen D, Ghazanfari R, Sobiesiak M, Harichandan A, Mortha E, Petkova N, Grimm S, Cerabona F, de Zwart P, Abele H, Aicher WK, Faul C, Kanz $\mathrm{L}$ and Buhring HJ. Phenotypic and functional heterogeneity of human bone marrow- and amnion-derived MSC subsets. Annals of the New York Academy of Sciences. 2012; 1266:94-106.

107. Strioga M, Viswanathan S, Darinskas A, Slaby O and Michalek J. Same or not the same? Comparison of adipose tissue-derived versus bone marrow-derived mesenchymal stem and stromal cells. Stem cells and development. 2012; 21:2724-2752.

108. Pevsner-Fischer M, Levin S and Zipori D. The origins of mesenchymal stromal cell heterogeneity. Stem cell reviews. 2011; 7:560-568.

109. Barry F and Murphy M. Mesenchymal stem cells in joint disease and repair. Nature reviews Rheumatology. 2013; 9:584-594.

110. Li Y, Xu J, Mao L, Liu Y, Gao R, Zheng Z, Chen W, Le A, Shi S and Wang S. Allogeneic mesenchymal stem cell therapy for bisphosphonate-related jaw osteonecrosis in Swine. Stem cells and development. 2013; 22:2047-2056.

111. Heldman AW, DiFede DL, Fishman JE, Zambrano JP, Trachtenberg BH, Karantalis V, Mushtaq M, Williams AR, Suncion VY, McNiece IK, Ghersin E, Soto V, Lopera G, Miki R, Willens H, Hendel R, et al. Transendocardial mesenchymal stem cells and mononuclear bone marrow cells for ischemic cardiomyopathy: the TAC-HFT randomized trial. Jama. 2014; 311:62-73.

112. Karantalis V, DiFede DL, Gerstenblith G, Pham S, Symes J, Zambrano JP, Fishman J, Pattany P, McNiece I, Conte J, Schulman S, Wu K, Shah A, Breton E, Davis-Sproul J, Schwarz R, et al. Autologous mesenchymal stem cells produce concordant improvements in regional function, tissue perfusion, and fibrotic burden when administered to patients undergoing coronary artery bypass grafting: The Prospective Randomized Study of Mesenchymal Stem Cell Therapy in Patients Undergoing Cardiac Surgery (PROMETHEUS) trial. Circulation research. 2014; 114:1302-1310.

113. Gnecchi M, Danieli P and Cervio E. Mesenchymal stem cell therapy for heart disease. Vascular pharmacology. 2012; 57:48-55.

114. Skrahin A, Ahmed RK, Ferrara G, Rane L, Poiret T, Isaikina $\mathrm{Y}$, Skrahina A, Zumla A and Maeurer MJ. Autologous mesenchymal stromal cell infusion as adjunct treatment in patients with multidrug and extensively drugresistant tuberculosis: an open-label phase 1 safety trial. The 
Lancet Respiratory medicine. 2014; 2:108-122.

115. Abdel-Mageed AS, Senagore AJ, Pietryga DW, Connors RH, Giambernardi TA, Hay RV and Deng W. Intravenous administration of mesenchymal stem cells genetically modified with extracellular superoxide dismutase improves survival in irradiated mice. Blood. 2009; 113:1201-1203.

116. Hu KX, Sun QY, Guo M and Ai HS. The radiation protection and therapy effects of mesenchymal stem cells in mice with acute radiation injury. The British journal of radiology. 2010; 83:52-58.

117. Lange C, Brunswig-Spickenheier B, Cappallo-Obermann H, Eggert K, Gehling UM, Rudolph C, Schlegelberger B, Cornils K, Zustin J, Spiess AN and Zander AR. Radiation rescue: mesenchymal stromal cells protect from lethal irradiation. PloS one. 2011; 6:e14486.

118. Kudo K, Liu Y, Takahashi K, Tarusawa K, Osanai M, Hu DL, Kashiwakura I, Kijima H and Nakane A. Transplantation of mesenchymal stem cells to prevent radiation-induced intestinal injury in mice. Journal of radiation research. 2010; 51:73-79.

119. Chang P, Qu Y, Liu Y, Cui S, Zhu D, Wang H and Jin $X$. Multi-therapeutic effects of human adipose-derived mesenchymal stem cells on radiation-induced intestinal injury. Cell death \& disease. 2013; 4:e685.

120. Wang R, Zhu CZ, Qiao P, Liu J, Zhao Q, Wang KJ and Zhao TB. Experimental treatment of radiation pneumonitis with human umbilical cord mesenchymal stem cells. Asian Pacific journal of tropical medicine. 2014; 7:262-266.

121. Schmidt M, Haagen J, Noack R, Siegemund A, Gabriel P and Dorr W. Effects of bone marrow or mesenchymal stem cell transplantation on oral mucositis (mouse) induced by fractionated irradiation. Strahlentherapie und Onkologie : Organ der Deutschen Rontgengesellschaft [et al]. 2014; 190:399-404.

122. Francois S, Bensidhoum M, Mouiseddine M, Mazurier C, Allenet B, Semont A, Frick J, Sache A, Bouchet S, Thierry D, Gourmelon P, Gorin NC and Chapel A. Local irradiation not only induces homing of human mesenchymal stem cells at exposed sites but promotes their widespread engraftment to multiple organs: a study of their quantitative distribution after irradiation damage. Stem cells. 2006; 24:1020-1029.

123. Mouiseddine M, Francois S, Semont A, Sache A, Allenet B, Mathieu N, Frick J, Thierry D and Chapel A. Human mesenchymal stem cells home specifically to radiationinjured tissues in a non-obese diabetes/severe combined immunodeficiency mouse model. The British journal of radiology. 2007; 80 Spec No 1:S49-55.

124. Konoplyannikov AG, Petriev VM, Konoplyannikova OA, Kal'sina S, Lepechina LA, Smorizanova OA, Semenkova IV and Agaeva EV. Effects of (60)co whole-body gammairradiation in different doses on the distribution of (188)Relabeled autologous mesenchymal stem cells in wistar rats after intravenous (systemic) transplantation during different periods after exposure. Bulletin of experimental biology and medicine. 2008; 145:520-525.
125. Semont A, Francois S, Mouiseddine M, Francois A, Sache A, Frick J, Thierry D and Chapel A. Mesenchymal stem cells increase self-renewal of small intestinal epithelium and accelerate structural recovery after radiation injury. Advances in experimental medicine and biology. 2006; 585:19-30.

126. Yan X, Liu Y, Han Q, Jia M, Liao L, Qi M and Zhao RC. Injured microenvironment directly guides the differentiation of engrafted Flk-1(+) mesenchymal stem cell in lung. Experimental hematology. 2007; 35:1466-1475.

127. Deng W, Han Q, Liao L, Li C, Ge W, Zhao Z, You S, Deng $\mathrm{H}$, Murad F and Zhao RC. Engrafted bone marrow-derived flk-(1+) mesenchymal stem cells regenerate skin tissue. Tissue engineering. 2005; 11:110-119.

128. Chapel A, Bertho JM, Bensidhoum M, Fouillard L, Young RG, Frick J, Demarquay C, Cuvelier F, Mathieu E, Trompier F, Dudoignon N, Germain C, Mazurier C, Aigueperse J, Borneman J, Gorin NC, et al. Mesenchymal stem cells home to injured tissues when co-infused with hematopoietic cells to treat a radiation-induced multi-organ failure syndrome. The journal of gene medicine. 2003; 5:1028-1038.

129. Huang CK, Lee SO, Luo J, Wang R, Dang Q and Chang C. A mouse model of liver injury to evaluate paracrine and endocrine effects of bone marrow mesenchymal stem cells. Methods in molecular biology. 2014; 1213:69-79.

130. Gao Z, Zhang Q, Han Y, Cheng X, Lu Y, Fan L and $\mathrm{Wu} \mathrm{Z}$. Mesenchymal stromal cell-conditioned medium prevents radiation-induced small intestine injury in mice. Cytotherapy. 2012; 14:267-273.

131. Chapel A, Francois S, Douay L, Benderitter M and Voswinkel J. New insights for pelvic radiation disease treatment: Multipotent stromal cell is a promise mainstay treatment for the restoration of abdominopelvic severe chronic damages induced by radiotherapy. World journal of stem cells. 2013; 5:106-111.

132. Chapel A, Francois S, Douay L, Benderitter M and Voswinkel J. Fifteen years of preclinical and clinical experiences about biotherapy treatment of lesions induced by accidental irradiation and radiotherapy. World journal of stem cells. 2013; 5:68-72.

133. Kursova LV, Konoplyannikov AG, Pasov VV, Ivanova IN, Poluektova MV and Konoplyannikova OA. Possibilities for the use of autologous mesenchymal stem cells in the therapy of radiation-induced lung injuries. Bulletin of experimental biology and medicine. 2009; 147:542-546.

134. Maalouf M, Durante M and Foray N. Biological effects of space radiation on human cells: history, advances and outcomes. Journal of radiation research. 2011; 52:126-146.

135. Durante M and Cucinotta FA. Heavy ion carcinogenesis and human space exploration. Nature reviews Cancer. 2008; 8:465-472.

136. Miousse IR, Shao L, Chang J, Feng W, Wang Y, Allen AR, Turner J, Stewart B, Raber J, Zhou D and Koturbash 
I. Exposure to low-dose (56)Fe-ion radiation induces long-term epigenetic alterations in mouse bone marrow hematopoietic progenitor and stem cells. Radiation research. 2014; 182:92-101.

137. Tabocchini MA, Campa A and Dini V. DNA and cellular effects of charged particles. Health physics. 2012; 103:547555.

138. Yang HY, Qu RM, Lin XS, Liu TX, Sun QQ, Yang C, Li XH, Lu W, Hu XF, Dai JX and Yuan L. IGF-1 from adipose-derived mesenchymal stem cells promotes radioresistance of breast cancer cells. Asian Pacific journal of cancer prevention : APJCP. 2014; 15:10115-10119.

139. Klopp AH, Spaeth EL, Dembinski JL, Woodward WA, Munshi A, Meyn RE, Cox JD, Andreeff M and Marini FC. Tumor irradiation increases the recruitment of circulating mesenchymal stem cells into the tumor microenvironment. Cancer research. 2007; 67:11687-11695.

140. Chen J, Zhang ZG, Li Y, Wang L, Xu YX, Gautam SC, $\mathrm{Lu}$ M, Zhu Z and Chopp M. Intravenous administration of human bone marrow stromal cells induces angiogenesis in the ischemic boundary zone after stroke in rats. Circulation research. 2003; 92:692-699.

141. Todeschi MR, El Backly R, Capelli C, Daga A, Patrone $\mathrm{E}$, Introna $\mathrm{M}$, Cancedda $\mathrm{R}$ and Mastrogiacomo $\mathrm{M}$. Transplanted Umbilical Cord Mesenchymal Stem Cells Modify the In Vivo Microenvironment Enhancing Angiogenesis and Leading to Bone Regeneration. Stem Cells Dev. 2015; 24:1570-81.

142. Pacini S and Petrini I. Are MSCs angiogenic cells? New insights on human nestin-positive bone marrow-derived multipotent cells. Frontiers in cell and developmental biology. 2014; 2:20.

143. Caplan AI. All MSCs are pericytes? Cell stem cell. 2008; 3:229-230.

144. Bautch VL. Stem cells and the vasculature. Nature medicine. 2011; 17:1437-1443.

145. Eterno V, Zambelli A, Pavesi L, Villani L, Zanini V, Petrolo G, Manera S, Tuscano A and Amato A. Adipose-derived Mesenchymal Stem Cells (ASCs) may favour breast cancer recurrence via HGF/c-Met signaling. Oncotarget. 2014; 5:613-633. 